\title{
Impact of Spiritual Practices on Well-Being among Madarsa and University Students
}

\author{
Mohd. Ahamar Khan ${ }^{1}$

\section{ABSTRACT:}

The purpose of this study was to find out the impact of spiritual practices on wellbeing among Madarsa and University students. The sample consisted of $100(n=50$ Madarsa and $n=50$ University students) participants. Spiritual Practices Scale (M) and Well Being Scale, was used to collect the data. Simple Linear Regression, Correlation and t-test were used for data analyses. The findings of this study revealed that, there is positive and significant influence of spiritual practices on overall wellbeing of students. There was also significant influence of spiritual practices on wellbeing of Madarsa as well as University students. Further t-test was applied and significant difference was found between spiritual practices as well as wellbeing of Madarsa and University students. This study has good significance in practical life; it could serve as a guide to increase student's spiritual practices to maximize wellbeing.

Keywords: Spiritual practices, Wellbeing, Madarsa and University Students.

\section{INTRODUCTION:}

Every person is born with their own spirit in the world. So, spirituality is essential part of each and every person's lives around the world. Spirituality can be developed by the spiritual practices among the people. Those people who regularly involve such types of spiritual practices, they experience its extra-ordinary effects. Although, the forms of spiritual practices may vary across the culture and religion, but it is universally prevalent. Due to the variation of spiritual practices, researcher made an idea to see the influence of Islamic spiritual practices on wellbeing. For this purpose, this study was carried out on Madarsa and University students. Because of Madarsa and University educational environment are quite different in terms of spiritual practices. Madarsa educational environment fully based on Islamic spiritual practices, while University educational system does not comprises with spiritual practices.

${ }^{1}$ Research Scholar, Department of Psychology, Aligarh Muslim University, Aligarh

(C) 2015 I A Khan; licensee IJIP. This is an Open Access Research distributed under the terms of the Creative Commons Attribution License (http://creativecommons.org/licenses/by/2.0), which permits unrestricted use, distribution, and reproduction in any Medium, provided the original work is properly cited. 


\section{Spirituality}

Elkins and others (1988) propounded a humanistic definition of spirituality. According to them, "spirituality is a way of being and experiencing that comes about through awareness of a transcendent dimension and that is characterized by certain identifiable values in regard to self, others, nature, life and whatever one considers to be the ultimate". Vrinte (1996),defined spirituality as "it is inspired and sustained by transpersonal experiences that originate in the deepest recesses of the human being and they are but natural modifications of that domain of the human psyche and that contains greater depth of life'. Perrin (2007) proposed spirituality in terms of spirit. According to him, the spirit refers to human consciousness, a constitutive dimension of human beings, and to capacity for self consciousness. Kabbani (2008) argued spirituality as a powerful weapon. He said it a struggle between acceptance and non acceptance, belief or unbelief. Burkhardt (2007) suggest that "trying to define spirituality is akin to trying to lasso the wind. The wind is sensed and felt, and its effect on us and things around us is seen, but it cannot be contained within imposed boundaries, or even the best definitions".

Kuhalampi (2010) listed the following features of spirituality.

Meaning the ontological significance of life; making sense of life situations; deriving purpose in existence.

Value beliefs and standards that are cherished; having to do with the truth, beauty, worth of a thought, object or behaviour; often discussed as ultimate values.

Transcendence experience and appreciation of a dimension beyond the self; expanding self -boundaries.

Connecting relationship with self, others, God, and the environment.

Becoming an unfolding of life that demands reflection and experience; including a sense of who one is and how one knows.

Hope a prospect of confidence and trust towards the future.

\section{Dimensions of Spirituality}

Spirituality is better understood as a multidimensional space in which every individual can be located (Larson, Sawyers \& McCullough, 1998). Sims (1994) propounded five dimensions viz., meaning in life, interrelatedness, wholeness, morality, and awareness of God. 
Glock and Stark (1965) proposed four elements or domains all of which are related with the context of religion: the experiential, the ritualistic, the intellectual and the consequential. Capps and others (1976) identified six spiritual dimensions within religion; the mythological, ritual, experiential, dispositional, social and directional. Elkins et al (1988) offered nine core dimensions of spirituality: transcendent, meaning and purpose in life, mission in life, sacredness of life, material values, altruism, idealism, and awareness of the tragic and the fruits of spirituality. Karasu (1999) suggested the three ways to spirituality in the context of belief: belief in the sacred, belief in unity and belief in transformation.

Miller and Thorensen (2000) propounded three broad measurement domains; spiritual practices, beliefs and experiences. These three domains are meant to characterize spirituality within and outside the context of religion and are consistent with a psychological perspective that is sensitive to cultural, ethnic, socio-economic and religious differences.

\section{Spiritual Practices}

Spiritual practices may be observed easily because it focuses attention on overt observable behaviour (e.g. Connors, Tongon \& Miller, 1996). Ibn 'Arabi' categorised four stages of practice in Sufism namely; Sharia (exoteric religious law), Tariqa (the mystical path), Haqiqah (truth), and Marifa (gnosis) (Ozak, 1988). People engage in various types of spiritual practices such as prayer, meditation, fasting, visiting Holy shrines, attending religious congregation, charity, and pilgrimage. Religion and spirituality are traditional means of coping, as they promote an internal locus of control in stressful situations (Barbarin, 1993; Hefti, 2011). According to the Allport, 'I feel equally sure that mental health facilitated by an intrinsic, but not an extrinsic, religious orientation'. Loewenthal et al. (2001) conducted a study on depressed people among Christians, Jews, Muslims, Hindus, followers of other religions and non-religious people living in the UK and found that Muslims believed more strongly than as compare to other faith groups in the efficacy of every form of religious activity in coping with depression.

\section{Well-being}

World Health Organization (WHO, 1952) defined optimal health as "a state of complete physical mental and social well-being and not merely the absence of disease or infirmity." They also summed spiritual well-being as one dimension of well-being. Archer and Gage (1987) defined well-being as the "Process and state of quest for maximum human functioning that involves the body, mind and spirit."

The Oxford English Dictionary (Simpson and Weiner, 1989) defined well-being as, "A state of being or doing well in life, happy, healthy or prosperous condition; moral or physical welfare". According to Singh (1999), well-being covers all aspects of health namely: physical, mental, 
social, emotional and spiritual. Schneiders (1965) proposed mental well-being as follows: (1) Mental efficiency ; (2) Control and integration of motives; (3) Control of conflicts and frustrations; (4) Positive and healthy feelings and emotions; (5) Tranquility of peace of mind; (6) Healthy attitudes; (7) Healthy self concepts; (8) Adequate ego identity; (9) Adequate relation to reality. Myers(1992) conceptualized spiritual well-being as " a continuous search for meaning and purpose in life, appreciation for depth of life, the expanse of universe and natural forces which operate a personal belief system."

\section{LITERATURE REVIEW}

Myers and Diener (1995) in a random survey had done in a sixteen nations and found that religious involvement is associated with higher well-being, optimism, and positive expectations for the future. Lee and Ishii-Kuntz (1987) in a survey among 2,872 those persons whose age was 55 or over on social interaction, loneliness and well being among men and found that religious attendance was significantly and positively related with morale $(\mathrm{p}=.02)$, after controlling for ten other variables, including all the social variables.

Helm et al. (2000) had studied the effect of prayer on mortality and found an association between private religious activity and longer survival in certain population subgroups. Daniels and Harris (2000), in their study found the strongest relation between well-being and performance. Various investigators have deeply investigated the impact of personality on well-being, and found that the strongest and most dependable factor underlying differences in well-being between persons (Tellegen, David, Thomas, Kimerly, Nancy and Stephen 1988; Hayes and Joseph 2003).

Radcliff (2001) found that the ideological complexion of governments and levels of well-being are positively related to each other. He also shows a positive correlation between qualitative features of the welfare state well-being. Hellgren and Sverke(2001) found that the variables such as age, gender, education, work, family status, and tenure in organization influence to wellbeing.

\section{OBJECTIVES OF THE STUDY:}

> To determine the influence of spiritual practices on well-being among overall students.

$>$ To determine the influence of spiritual practices on well-being among Madarsa students.

$>$ To determine the influence of spiritual practices on well-being among University students.

To determine the difference between Madarsa and University students on spiritual practices and well-being. 
Impact of Spiritual Practices on Well-Being among Madarsa and University Students

\section{HYPOTHESES OF THE STUDY:}

$>$ There will be significant influence of spiritual practices on well-being among overall students.

There will be significant influence of spiritual practices on well-being among Madarsa students.

$>$ There will be significant influence of spiritual practices on well-being among University students.

There will be significant difference between Madarsa and University students on spiritual practices and well-being.

\section{Sample of the Study}

In the present study sample was consisted of 100 Muslim male students (age 18 to 25), 50 each from Aligarh Muslim University and different Madarsas of Aligarh. The data was collected by simple random sampling technique.

\section{Tools Used}

In psychological researches, psychological tools play very important role especially with regard to the reliability and validity of the tools. The two different scales namely; Spiritual Practices Scale (Muslim) and Well-Being Scale, were used for data collection. The brief description of the scales used in the present investigation is presented in the following manner.

\section{Spiritual Practices Scale (Muslim)}

This scale was developed by Husain and Singh (2014). This scale consists of fourteen items. Minimum and maximum score ranges between14 to 64 . The internal consistency reliability of this scale was found to be 0.67 . The construct validity of this scale was found to be 0.53 . The content validity of this scale has also been found quite satisfactory.

\section{Well Being Scale}

This scale was developed by Singh and Gupta (2001). This scale consisted of five sub-scale namely; physical wellbeing, mental well being, social well being, emotional well being and spiritual well being. Each sub-scale has ten items and there are 50 items in total. Scores on all the sub-scale added up to get a composite score as total well being. Minimum and maximum score can be 50 and 250 respectively. It consists of 29 positive items and 21 negative items. The testretest reliability of the scale was 0.98 and split half reliability was found 0.96 . Content and concurrent validity of the Well being Scale was found to be well established. Concurrent validity of the scores of well being scale was determined by comparing it with the scores of Subjective Well being Inventory Sall and Nagpal (1992). 


\section{Procedure of Data Collection}

Good rapport was established with participants before requesting to fill up the questionnaire and then instructions were invariably explained to the participants. After that questionnaires were distributed individually. Subjects were assured of confidentiality of their responses and were requested to extend their co-operation. Finally questionnaires were collected from all the participants, scoring done and analysis was carried on.

\section{STATISTICAL ANALYSES AND RESULTS}

Table-1: Represent Simple Linear Regression analysis, Spiritual Practices as predictor of Wellbeing among Overall Students.

Model Summary

\begin{tabular}{|l|l|l|l|l|}
\hline Model & $R$ & R Square & $\begin{array}{l}\text { Adjusted } \\
\text { Square }\end{array}$ & $\begin{array}{l}\text { R } \\
\text { Change Statistics R } \\
\text { Square change }\end{array}$ \\
\hline 1 & $.818^{\mathrm{a}}$ & .668 & .662 & .668 \\
\hline
\end{tabular}

a. Predictors: (Constant), Spiritual Practices overall

The above table shows the model summary indicating one predictor (spiritual practices) of the model, in which correlation between spiritual practices and well-being was found to be $\mathrm{R}=.818$. Further R square change was found to be .668 which represents the $66.8 \%$ actual contribution of predictor variable (spiritual practices) to criterion variable (well-being).

Table-2: Showing the Coefficient details of Spiritual Practices and Well-being of Overall Students $(\mathrm{N}=100)$.

Coefficients $^{\mathrm{a}}$

\begin{tabular}{|c|c|c|c|c|c|c|c|}
\hline \multirow{2}{*}{\multicolumn{3}{|c|}{ Model }} & \multicolumn{2}{|c|}{$\begin{array}{l}\text { Unstandardized } \\
\text { Coefficients }\end{array}$} & \multirow{2}{*}{\begin{tabular}{|l}
$\begin{array}{l}\text { Standardized } \\
\text { Coefficients }\end{array}$ \\
Beta
\end{tabular}} & \multirow[b]{2}{*}{$\mathrm{T}$} & \multirow[b]{2}{*}{ Sig. } \\
\hline & & & B & Std. Error & & & \\
\hline \multirow[t]{2}{*}{1} & (Constant) & & 145.935 & 25.655 & & 5.688 & .000 \\
\hline & $\begin{array}{l}\text { Spiritual } \\
\text { Overall }\end{array}$ & Practices & 2.472 & .251 & .818 & 9.837 & .000 \\
\hline
\end{tabular}

a. Dependent Variable: Wellbeing Overall 
The above table indicates that the value of $\beta=.818$ shows the spiritual practices positively related with well-being of overall students. The t-value found to be 9.837 , which was significant at 0.01 level for spiritual practices. Thus, the first underlined hypothesis of the present investigation that ("there will be significant influence of spiritual practices on well-being among overall students") is proved.

Table-3: Represent Simple Linear Regression analysis, Spiritual Practices as predictor of Wellbeing among Madarsa Students.

\begin{tabular}{|l|l|l|l|l|}
\hline Model & R & R Square & $\begin{array}{l}\text { Adjusted } \\
\text { Square }\end{array}$ & $\begin{array}{l}\text { Change Statistics R } \\
\text { Square change }\end{array}$ \\
\hline 1 & $.973 \mathrm{a}$ & .947 & .946 & .947 \\
\hline
\end{tabular}

a. Predictors: (Constant), Spiritual Practices Madarsa

The above table shows the model summary indicating one predictor (spiritual practices) of the model, in which correlation between spiritual practices and well-being was found to be $\mathrm{R}=.973$. Further R square change was found to be .947 which represents the $94.7 \%$ actual contribution of predictor variable (spiritual practices) to criterion variable (well-being).

Table-4: Showing the Coefficient details of Spiritual Practices and Well-being of Madarsa Students $(\mathrm{N}=50)$.

Coefficients $^{\mathrm{a}}$

\begin{tabular}{|c|c|c|c|c|c|c|c|}
\hline & & & \multicolumn{2}{|c|}{$\begin{array}{l}\text { Unstandardized } \\
\text { Coefficients }\end{array}$} & $\begin{array}{l}\text { Standardized } \\
\text { Coefficients }\end{array}$ & \multirow[b]{2}{*}{$\mathrm{t}$} & \multirow[b]{2}{*}{ Sig. } \\
\hline \multicolumn{3}{|c|}{ Model } & B & Std. Error & Beta & & \\
\hline \multirow[t]{2}{*}{1} & (Constant) & & -94.656 & 10.717 & & -8.832 & .000 \\
\hline & $\begin{array}{l}\text { Spiritual } \\
\text { Madarsa Total }\end{array}$ & Practices & 5.476 & .188 & .973 & 29.190 & .000 \\
\hline
\end{tabular}

a. Dependent Variable: Well-Being Madarsa

The above table indicates that the value of $\beta=.973$ shows the spiritual practices positively related with well-being of overall students. The t-value found to be 29.190 , which was significant at 0.01 level for spiritual practices. Thus, the second underlined hypothesis of the present 
investigation that ("there will be significant influence of spiritual practices on well-being among Madarsa students"') is proved.

Table-5: Represent Simple Linear Regression analysis, Spiritual Practices as predictor of Wellbeing among University Students.

\section{Model Summary}

\begin{tabular}{|l|l|l|l|l|}
\hline & & & & $\begin{array}{l}\text { Change } \\
\text { Statistics } \\
\text { Square } \\
\text { Model }\end{array}$ \\
\hline 1 & $\mathrm{R}$ & $\mathrm{R}$ Square & $\begin{array}{l}\text { Adjusted } \\
\text { Square }\end{array}$ \\
\hline
\end{tabular}

a. Predictors: (Constant), Spiritual Practices University

The above table shows the model summary indicating one predictor (spiritual practices) of the model, in which correlation between spiritual practices and well-being was found to be $\mathrm{R}=.947$. Further R square change was found to be .897 which represents the $89.7 \%$ actual contribution of predictor variable (spiritual practices) to criterion variable (well-being).

Table-6: Showing the Coefficient details of Spiritual Practices and Well-being of University Students $(\mathrm{N}=50)$.

Coefficients $^{\mathrm{a}}$

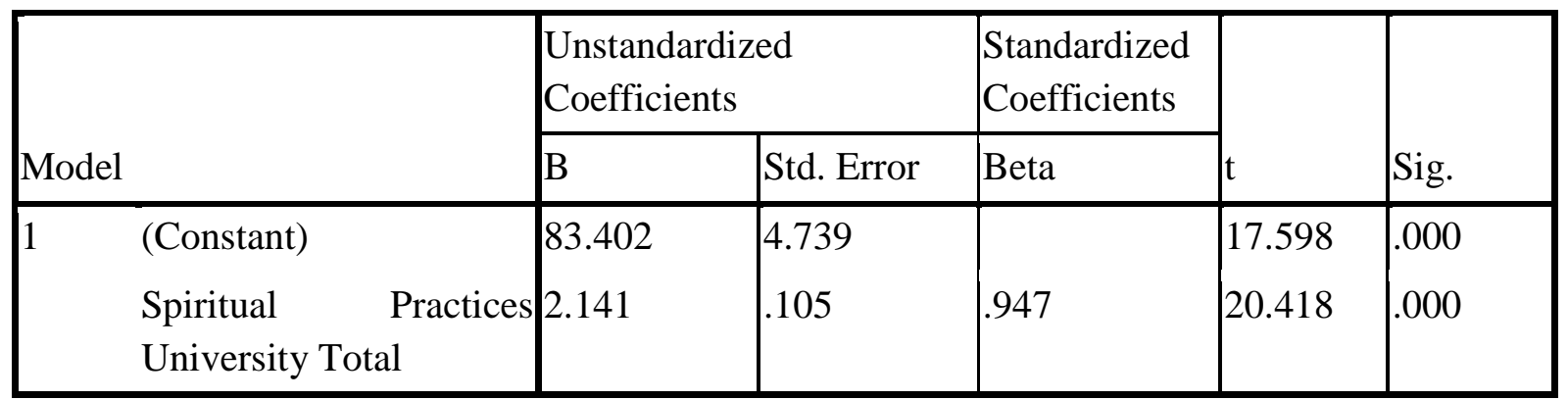

a. Dependent Variable: Wellbeing University

The above table indicates that the value of $\beta=.947$ shows the spiritual practices positively related with well-being of University students. The t-value found to be 20.418 , which was significant at 0.01 level for spiritual practices. Thus, the third underlined hypothesis of the present investigation 
that ("there will be significant influence of spiritual practices on well-being among University students") is proved.

Table-7: Mean SD and t-value of Madarsa and University Students on Spiritual Practices and Well-Being.

\begin{tabular}{|l|l|l|l|l|l|}
\hline \multirow{2}{*}{ Variables } & Groups & $\mathrm{N}$ & Mean & SD & $\begin{array}{l}\text { t-value } \\
(\mathrm{df}=98)\end{array}$ \\
\hline \multirow{2}{*}{ Spiritual Practices } & Madarsa & 50 & 57.10 & 1.992 & \multirow{2}{*}{$13.52^{* *}$} \\
\cline { 2 - 6 } & University & 50 & 44.80 & 6.108 & \\
\hline \multirow{2}{*}{ Well-being } & Madarsa & 50 & 218.00 & 11.212 & \multirow{2}{*}{$16.83^{* *}$} \\
\cline { 2 - 5 } & University & 50 & 179.30 & 11.807 & \\
\hline
\end{tabular}

**. Significant at the 0.01 level

The Mean and SD in the case of Madarsa students on spiritual practices were found to be57.10 and 1.992, while in the case of University students were found to be 44.8 and 6.108 respectively. The t-value between two means was found to be13.52 which was significant at 0.01level. On the other hand the Mean and SD of Madarsa students on well-being were found to be 218 and 11.212, while in the case of University students were found to be179.3 and 11.807 respectively. The t-value between two means was found to be16.83 which was significant at 0.01level. Thus, the fourth underlined hypothesis of the present investigation that ("there will be significant difference between spiritual practices and well-being among Madarsa and University students ") is proved.'

\section{DISCUSSION}

The above findings of this study clearly indicate that spiritual practices significantly influence well-being of Madarsa, University, and overall students. These findings are supported by several research studies such as; spiritual practices enhance the well-being (Koenig et al., 1988; Meisenhelder and Marcum 2004; Hartmann 2006). Myers and Diener (1995) conducted random survey in a sixteen nations and they also found that religious involvement is associated with higher well-being, optimism, and positive expectations for the future.

Further, the obtained result shows significant difference between spiritual practices and wellbeing among Madarsa and University students. The result also shows higher mean scores on 
Impact of Spiritual Practices on Well-Being among Madarsa and University Students

spiritual practices and well-being among Madarsa students as compare to the University students. Madarsa educational environment constitutes with Islamic spiritual practices. In contrast university educational environment is quite different from Madarsa with respect to spiritual practices. Madarsa students daily perform various spiritual practices such as; Prayer (salat), Recitation of Holy Quran, Meditation (Zikr, Aurad, and Wazaif) etc. While at the same time University students have been found rarely involved in such spiritual practices and rituals. Therefore, the level of spirituality in the case of University students have been found on the lower side as compare to Madarsa's students.

\section{CONCLUSION}

Finally, it is concluded that spiritual practices positively related with overall well-being. It means that frequently involvement in spiritual practices strengthened well-being of the students. Results of the present investigation shows higher well-being among Madarsa students, because of they frequently perform Islamic spiritual practices in daily life as compare to the University students. It is mentioned in Holy Quran and Hadith that Islamic spiritual practices play significant role in managing psychological distress and developing physical fitness as well as inner relief. Now in a present dynamic life, people experience a large number of major as well as chronic psychological distresses, which adversely affected our life in major forms of divorce and suicidal attempts. According to the past literature, theories, and present findings; if we will regularly perform spiritual practices then it will enhance our well-being and save our golden life.

\section{REFERENCES}

Archer, J., B.S. Probert and L. Gage (1987). College students' attitude toward wellness. Journal of college student personnel, 28 (4), 311-317. As cited by J. E. Myers. Wellness, Prevention, Development: The cornerstone of the profession. Journal of counseling and Development, 71 (2), 136139.

Burkhardt, M. A. (2007). Commentary on spirituality in nursing and health-related literature: A concept analysis. Journal of holistic Nursing, 25 (4), 263-274.

Barbarin, O. (1993). Coping and resilience: Exploring the inner lives of African American children. Journal of Black Psychology, 19, 472-498.

Capps, D., Rambo, L. \& Ransohoff, P. (1976). Psychology of religion. Detroit, MI: Gale Research.

Connors, G.J., Tongon, J.S.\& Miller,W.R.(1996 ). A measure of religious background and behaviour for use in behaviour change research. Psychology of Addictive Behaviour, 10, 90-96.

Daniels, K. and Harris, C. "Work, Psychological well-being and performance", Occupational Medicine, Vol. 50, No. 5, pp. 304-309, 2000. 
Impact of Spiritual Practices on Well-Being among Madarsa and University Students

Elkins, D. N., Hughes, L.L., Saunders, C., Leaf, J. A. \& Headstrom, L. J. (1988). Towards a Humanistic Phenomenological Spirituality: Definition, Description and Measurement. Journal of Humanistic Psychology, 28, (4), 5-18.

Glock, C.Y. \& Stark, R. (1965). Religion and society in tension. Chicago: Rand McNally.

Gordon W. Allport, The Person in Psychology: Selected Essays (Boston: Beacon Press, 1968), p.150.

Hartmann, Thom. Walking your blues away: how to heal the mind and create emotional well-being. Rochester, Vt.: Park Street Press, 2006. Print.

Hayes, N. and Joseph, S. "Big 5 correlates of three measures of subjective well-being", Personality and Individual Differences,Vol. 34, No. 4, pp. 723-727, 2003.

Hefti, R. (2011). Integrating religion and spirituality into mental health care, psychiatry and psychotherapy. Religions, 2, 611-627.

Hellgren, J. and Sverke, M. "Unionized employees' perceptions of role stress and fairness during organizational downsizing: Consequences for job satisfaction, union satisfaction, and well-being", Economic and Industrial Democracy, Vol. 22, pp. 543-567, 2001.

Helm, H., Hays, J. C., Flint, E., Koenig, H.G., Blazer, D. G. (2000). Effects of private religious activity on mortality of elderly disabled and nondisabled adults. Journal of Gerontology (Medical Sciences), 55A, M400-M405.

Husain, A. \& Singh, R. (2014).Spiritual Practices Scale for Muslim (In Press).

Kabbani, S. M. H. (2008). Sufism and the perennial conflict of good and evil. Horizons of Spiritual Psychology. New Delhi : Global Vision Publishing House.

Karasu, T. B.(1999). Spiritual Psychotherapy. American Journal of Psychotherapy; 53, (2) 143-163.

Koenig, H. G., George, L. K., and Siegler, I. C. (1988). The use of religion and other emotion- regulating coping strategies among older adults. Gerontologist, 28: 303-10.

Kuhalampi, H. (2010). Holistic Spirituality: In the thinking of Allen White, Painopaikka: Yliopistopaiono

Larson, D. B., Swyers, J. P., \& McCullough, M. E. (Eds.). (1998). Scientific research on spirituality and health: A consensus report. Rockville, MD: National Institute for Healthcare Research

Lee, G. R., \& Ishii-Kuntz, M. (1987). Social interaction, loneliness, and emotional well-being among the elderly. Research on Aging, 9, 359-482.

Loewenthal, K. M., Cinnirella, M., Evdoka, G., \& Morphy, P. (2001). Faith conquers all? Beliefs about the role of religious factors in coping with depression among different cultural religious groups in the UK. British Journal of Medical Psychology, 74, 293-303.

Meisenhelder, Janice B. and John Marcum. 2004. "Responses of Clergy to 9/11: Posttraumatic Stress, Coping, and Religious Outcomes." Journal for the Scientific Study of Religion 43:547-54. 
Impact of Spiritual Practices on Well-Being among Madarsa and University Students

Miller, W.R.\& Thoreson, C.E.(2000). Spirituality and health. In Miller W.R. (ed.) Integrating Spirituality into Treatment. Washington, DC: American Psychological Association, 1999. pp. 3-18.

Myers, D.G., \& Diener, E. (1995). Who is happy? Psychological Science ,6, 10-19.

Myers, J.E. (1992). Wellness through the life-span. Guidepost, 11. As cited by C.K. Chandler et al. Journal of Counselling and Development, 71 (2), 168-173.

Ozak,M.(Al Jerrahi).(1988).Irshad: Wisdom of a Sufi master. Amity, NY: Amity House.

Perrin, D. B. (2007). Studying Christian Spirituality. New York, London: Routledge.

Radcliff, B. "Politics, Markets and Life Satisfaction: The Political Economy of Human Happiness", American Political Science Review, Vol. 95, No. 4, pp. 939-952, 2001.

Schneiders, A. A. (1965). Personality dynamics \& mental health-principles of adjustment \& mental hygiene. New York: Holt, Rinehart and Wiliston, Inc.

Simpson, J. A. and Weiner, S.C. (1989). The Oxford English Dictionary: Walton Street, Oxford: Oxford University Press, 11, 676.

Sims, A. (1994). Psyche-spirit as well as mind? British Journal of Psychiatry. 165, 441-446.

Singh, Jagsharan Bir (1999). A study of well-being of navodaya vidyalaya teachers in relation to their job burnout. Unpublished Ph.D. Thesis, P.U., Chandigarh.

Singh, J. and Gupta, A. (2001). Well Being Scale, Department of Education, Chandigarh: Punjab University.

Tellegen, A., David, T.L., Thomas, J.B. Jr., Kimerly, J.W., Nancy, L.S.and Stephen, R. "Personality Similarity in Twins Reared Apart and Together", Journal of Personality and Social Psychology, Vol. 54,No. 6, pp. 1031-1039, 1988.

Vrinte, J. (1996). The Quest for the Inner Man: Transpersonal Psychotherapy and Integral Sadhana. New Delhi: Motilal Banrasidas.

World Health Organisation (1952). Handbook of basic documents. (Fourth Edition). Geneva, Switzerland: World health organization, 3. 